\title{
Ethno-Veterinary Practices for the Management of Common Diseases in Dairy Animals in Rural Punjab
}

\author{
S. Dey*, B. K. Sarkar and S. R. Paul \\ Department of Veterinary and Animal Husbandry Extension Education, College of Veterinary \\ Sciences and Animal Husbandry, R. K. Nagar, West Tripura-799008, India \\ *Corresponding author
}

\begin{abstract}
A B S T R A C T
The study was conducted for documentation of various ethno-veterinary practices (EVPs) followed in common diseases like mastitis, foot and mouth disease, ectoparasite infestation and diarrhoea in dairy animals of rural Punjab. Total 300 respondents were selected randomly from the villages of Punjab. Data was collected through a well-structured schedule through personal visits to the respective farmers. After analysis of the data, the farmers of Punjab were found to be using more than 20 number of EVPs practices. The EVPs employed at the time of mastitis included Azadirachta indica, Citrus limon, Piper nigrum, ammonium chloride, and Allium sativum. For foot and mouth disease, most important EVP is Whiskey spray around the shed and the animal, Lal dawai (KMnO4), Acacia arabica etc. The remedies for ectoparasites of animals included application of Kerosine oil, Eruca sativa, black oil and manual removal. The remedies for diarrhea include use of Punica granatum, Syzygium cumini, Nicotiana tabacum etc. These remedies were mostly prepared by pulverization, soaking/boiling in water and decoctions and administered per os. As per farmers' viewpoint, these EVPs proved to be very effective. Scientific documentations also proved their validation.
\end{abstract}

\section{Keywords}

Ethno-Veterinary Practices, common diseases, Cattle, Buffalo, Punjab

Article Info

\section{Accepted:}

05 June 2020

Available Online:

10 July 2020

\section{Introduction}

Ethno-veterinary practice (EVP) is based on folk beliefs, traditional knowledge, skills, methods and practices to cure diseases and maintain health of animals (Mathias-Mundy and McCorkle, 1989; Tabuti et al., 2003). Affordability is one of the most important virtues of the ethno-veterinary system. Drawbacks to modern veterinary practice include questionable quality of allopathic drugs, development of chemo-resistance in livestock and user unfriendly effects such as high antibiotic and hormone residues in the milk and other animal products (Fielding, 1998; Monteiro et al., 1998; Mathias, 2004).

Traditional veterinary medical knowledge systems is handed down orally from generation to generation which is disappearing because of rapid technological, socioeconomic, environmental, changes and as a result of loss of cultural heritage losses under the guise of civilization (Mathias- 
Mundy and McCorkle, 1989, Nfi et al., 2001). EVP is used for the maintenance of good animal health in developing countries (Kudi, 2003). The present study was undertaken to collect information on EVPs being used by the dairy farmers in the rural areas of Punjab over a one-year span of time for the management of common diseases in their dairy animals.

\section{Materials and Methods}

Data was collected randomly from 300 dairy farmers of rural Punjab through a well structured pre-tested schedule through personal visits to the respective farmers. For better representation of different regions of Punjab, the geographical area was divided into three zones- Sub-mountainous region, Central Planes and South-Western Plains. Information regarding use of any EVP at the time of various common diseases like mastitis, foot and mouth disease, ectoparasites and diarrhoea were collected. Efficacy of the particular EVP was judged from the outcome of that remedy as reported by the farmer. Later on its validity was confirmed by reviewing already published scientific reports.

\section{Results and Discussion}

Majority of the respondents were aged between 30-50 years (57.6\%). Most of them (54.6\% respondents) had been rearing 1-5 animals for $10-15$ years (39.3\% respondents). They had a monthly income between 10005000 rupees (57\% respondents). Similar findings had been reported earlier (Sharma, 2004).

During Mastitis a total of 7 EVPs comprising 4 based on plants and 3 based on combination of plants and chemicals were notified by 140 cattle owners. Azadirachta indica (neem) was the most frequently $(n=40)$, used plant followed by Citrus limon (lemon) $(\mathrm{n}=24)$. The use of Piper nigrum (black paper) has been reported by 13 respondents, ammonium chloride by 8 and Allium sativum (garlic) by 14 respondents. Materials other than plants were also used alone or in combination with plants (e.g., common salt+lemon) by other respondents. A number of EVPs were reported by the respondents for prevention and treatment of mastitis. In the present study Allium sativum (garlic) was one of the most effective plant for the treatment of mastitis in bovine. This plant has been reported in literature to be used for its antiseptic and vermifuge properties (Bullitta et al., 2007). Other treatment include lemon juice (antibacterial, antioxidant and acidifier property which decreases the milk $\mathrm{p}^{\mathrm{h}}$ ) mentioned in literature (Abbas et al., 2002), neem water has antiseptic property which is reported in literature (Uncini-Manganelli et al., 2001), $\mathrm{NH} 4 \mathrm{Cl}$ which have the property of acidifier which remove alkalosis is also reported (Pieroni et al., 2004), Piper nigrum have immunostimulatory, anti-inflammatory and antibacterial property (Uncini-Manganelli et al., 2001) and combination of these (e.g. neem water + lemon juice) are also being largely used in treatment of bovine mastitis. Plants were used for fomentation purpose to decrease udder inflammation. Similar type of practice with different species of plants has been reported in case of mastitis in camels in Saudi Arabia (Abbas et al., 2002).

In Foot and mouth disease a total of 7 EVPs were notified by 105 cattle owners. Most of the respondents are using combination of EVP and allopathic treatment because they believe EVP alone is not so effective in FMD. Whiskey spray around the shed and the animal was the most frequently $(n=27)$ used. Lal dawai (KMnO4) has been used by 21 respondents $(\mathrm{n}=21)$. The use of Acacia arabica (Indian gum) has been reported by 16 respondents, Allium sativum by 13 respondents, meat meal by 15 respondents, 
Whiskey spray+lal dawai has been used by 8 respondents and miscellaneous EVP (e.g. fish meal) used by 5 respondents. Most of these EVP practices are used in combination with allopathic treatment. In the present study EVP's used by the respondents includes whiskey spray (antiseptic) around the animal and the shed, lal dawai (KMnO4) which is antiseptic in nature (Uncini-Manganelli et al., 2001), acacia arabica (Indian gum) which have antiseptic, anodyne, anti-inflammatory and astringent property (Perveen and Bibi, 2008), Allium sativum (garlic) paste which has been reported in literature to be used for its antiseptic and vermifuge properties (Bullitta et al., 2007), meat meal and fish meal are used as protein supplement.

In the present study there was a strong agreement among some of the dairy owners that these types of infections do not find sole solution in EVM. They have to integrate the ethno-veterinary and allopathic treatment to cure the ailments. This is in close agreement with the statement made by dairy owners in other studies that EVM is not effective against acute infections e.g. foot-and-mouth disease (Kudi, 2003).

In ectoparasite infestation a total of 5 EVPs were notified by 217 cattle owners. Among the EVP followed Kerosine oil was the most frequently $(\mathrm{n}=75)$ used. Eruca sativa (taramira) has been used by 55 respondents $(n=55)$. The use of black oil (used engine oil) has been reported by 6 respondents, manual removal by 61 respondents, and miscellaneous EVP (e.g. combination of above mentioned practices e.g. kerosene+manual, black oil+kerosine) used by 20 respondents. One of the most frequently used EVP for external parasites were Eruca sativa (Tara mira) contains erucic acid which is effective against ectoparasite especially ticks (Bianco et al., 1997). In the present study kerosene oil was most frequently used by the respondents is having insecticide and antiseptic property (Nfi et al., 2001). Black oil (old engine oil) containing sulphur has been used in Africa as treatment of various skin conditions (Mathias-mundy and McCorkle, 1989). Other practice in the study includes manual removal. Use of copper sulphate in livestock for liver flukes is also reported ${ }^{15}$. Use of cow butter oil, local soap, spent engine oil for ectoparasites and skin infections is also reported (Kudi, 2003).

In diarrhea a total of 6 EVPs were notified by 100 cattle owners. Among the EVP followed Punica granatum (anar) was the most frequently $(\mathrm{n}=23)$ used. Syzygium cumini (jamun) has been used by 11 respondents $(\mathrm{n}=11)$. The use of Nicotiana tabacum (tobacco leaf) has been reported by 22 respondents, kortumba seeds by 15 respondents, Sesamum indicum (dried sesame leaves) by 13 respondents and miscellaneous EVP (dried tea leaves) used by 16 respondents. The common EVP's used by the respondents in diarrhea are- Nicotiana tabacum (tobacco leaf) has been reported in many studies. Nicotiana tabacum contains nicotine, anataline, nicotianin, minor alkaloids nornicotine, anabasine, coumarin scopoletin and polyphenoloxidase, (Wirtu et al., 1997; Guarrera, 1999; Lans et al., 2000; Nfi et al., 2001; Kudi, 2003; Muhammad et al., 2005) dry tea leaves (antioxidant) is also mentioned (Viegi et al., 2003), sesame leaves contains sesamol which is an antioxidant (Muhammad et al., 2005), Syzygium cumini is an astringent and antioxidant which is rich in vitamins and minerals are widely used in digestive disorders (Islam and Kashem, 1999), Punica granatum is also said to be an astringent and antioxident which is effective in diarrhea and dysentery (Muhammad et al., 2005), seeds of kortumba etc. are found effective. The antidiarrheal activity is said to be due to its inhibition of the increased watery secretions that occur in diarrhea (Lans et al., 2000). 
Table.1 EVPs used during treatment of mastitis

\begin{tabular}{|c|c|c|c|c|}
\hline SI No & EVP used & Dosages & Administration & $\begin{array}{l}\text { Positive response } \\
\text { as cited by the } \\
\text { respondents }\end{array}$ \\
\hline 1 & $\begin{array}{l}\text { Piper nigrum (pepper) } \\
(\mathrm{n}=13)\end{array}$ & $\begin{array}{l}\text { corn } 30-50 \mathrm{~g}+\mathrm{Jaggery} \\
150 \mathrm{~g}\end{array}$ & $\begin{array}{l}\text { pulverized, given PO } \\
\text { for 3-4 days }\end{array}$ & $\mathrm{n}=10(77 \%)$ \\
\hline 2 & Allium sativum $(\mathrm{n}=14)$ & L. bulb $250 \mathrm{~g}+$ Milk 2L & $\begin{array}{l}\text { Decoction drenched } \\
\text { for } 5 \text { days }\end{array}$ & $\mathrm{n}=11(78 \%)$ \\
\hline 3 & Ammonium chloride $(\mathrm{n}=8$ & $100 \mathrm{~g}+$ Water $2 \mathrm{~L}$ & given PO for 3 days & $\mathrm{n}=5(62 \%)$ \\
\hline 4 & Citrus limon $(n=24)$ & fruit extract $50-100 \mathrm{~g}$ & $\begin{array}{l}\text { raw juice given PO for } \\
3 \text { days }\end{array}$ & $\mathrm{n}=21(87.5 \%)$ \\
\hline 5 & $\begin{array}{l}\text { Azadirachta indica leaves } \\
(n=40)\end{array}$ & - & $\begin{array}{l}\text { boiled in water and } \\
\text { applied on the } \\
\text { infected teat }\end{array}$ & $\mathrm{n}=34(85 \%)$ \\
\hline 6 & $\begin{array}{l}\text { ammonium chloride } \\
(n=9)\end{array}$ & $\begin{array}{l}50-100 \mathrm{~g}+\text { citrus limon } \\
30 \mathrm{gm}+\text { Water } 1 \mathrm{~L}\end{array}$ & given $\mathrm{PO}$ for 3-5 days & $\mathrm{n}=6(67 \%)$ \\
\hline 7 & $\begin{array}{l}\text { Citrus limon + Azadirachta } \\
\text { indica leaves } \\
(n=22)\end{array}$ & $\begin{array}{l}50 g m+\text { Azadirachta } \\
\text { indica leaves }\end{array}$ & $\begin{array}{l}\text { boiled and applied } \\
\text { topically on the } \\
\text { swollen udder }\end{array}$ & $\mathrm{n}=20(91 \%)$ \\
\hline
\end{tabular}

Table.2 EVPs used during treatment of foot and mouth disease

\begin{tabular}{|l|l|c|c|c|}
\hline SI No & EVP used & Dosages & Administration & $\begin{array}{c}\text { Positive response as } \\
\text { cited by the } \\
\text { respondents }\end{array}$ \\
\hline $\mathbf{1}$ & Acacia arabica bark $(\mathrm{n}=16)$ & $125 \mathrm{~g}$ & $\begin{array}{c}\text { Boiled in water applied days } \\
\text { topically on vesicles for 5-6 }\end{array}$ & $\mathrm{n}=13(81 \%)$ \\
\hline $\mathbf{2}$ & Meat meal $(\mathrm{n}=15)$ & $250-500 \mathrm{~g}$ & $\begin{array}{c}\text { Cooked and given PO for } 2 \\
\text { days }\end{array}$ & $\mathrm{n}=9(60 \%)$ \\
\hline $\mathbf{3}$ & Allium sativum $(\mathrm{n}=13)$ & $100-150 \mathrm{gm}$ & $\begin{array}{c}\text { crushed and the paste } \\
\text { applied in the vesicles foe } 3 \\
\text { days }\end{array}$ & $\mathrm{n}=10(77 \%)$ \\
\hline $\mathbf{4}$ & $\begin{array}{l}\text { Whiskey spray+ Lal dawai } \\
(n=8)\end{array}$ & $\begin{array}{c}\text { few crystals of } \\
\text { Lal dawai }\end{array}$ & $\begin{array}{c}\text { Whiskey spray around the } \\
\text { shed and the animal and lal } \\
\text { dawai is applied in the } \\
\text { vesicles }\end{array}$ & $\mathrm{n}=6(75 \%)$ \\
\hline $\mathbf{5}$ & Lal dawai $(n=21)$ & few crystalls & $\begin{array}{c}\text { Mixed in warm water and } \\
\text { applied in the vesicles }\end{array}$ & $\mathrm{n}=18(86 \%)$ \\
\hline $\mathbf{6}$ & Fish meal $(n=5)$ & $250 \mathrm{gm}$ & $\begin{array}{c}\text { Cooked and given PO for } 2 \\
\text { days }\end{array}$ & $\mathrm{n}=3(60 \%)$ \\
\hline
\end{tabular}

Table.3 EVPs used during treatment of ectoparasite infestation

\begin{tabular}{|l|l|c|c|c|}
\hline SI No & EVP used & Dosages & Administration & $\begin{array}{c}\text { Positive response as } \\
\text { cited by the } \\
\text { respondents }\end{array}$ \\
\hline $\mathbf{1}$ & Kerosine oil $(\mathrm{n}=75)$ & - & Applied topically & $\mathrm{n}=64(85 \%)$ \\
\hline $\mathbf{2}$ & Eruca sativa $(\mathrm{n}=55)$ & $500 \mathrm{gm}$ & Given PO for 3 days & $\mathrm{n}=51(92 \%)$ \\
\hline $\mathbf{3}$ & Black oil $(\mathrm{n}=6)$ & - & Applied topically & $\mathrm{n}=5(83 \%)$ \\
\hline $\mathbf{4}$ & Manual removal $(\mathrm{n}=61)$ & - & - & $\mathrm{n}=49(80 \%)$ \\
\hline $\mathbf{5}$ & Miscellaneous EVP $(\mathrm{n}=20)$ & - & - & $\mathrm{N}=15(75 \%)$ \\
\hline
\end{tabular}


Table.4 EVPs used during treatment of diarrhea

\begin{tabular}{|c|c|c|c|c|}
\hline SI No & EVP used & Dosages & Administration & $\begin{array}{l}\text { Positive response } \\
\text { as cited by the } \\
\text { respondents }\end{array}$ \\
\hline 1 & $\begin{array}{l}\text { Punica granatum } \\
(\mathrm{n}=23)\end{array}$ & dried seed $250 \mathrm{~g}$ & $\begin{array}{c}\text { Given PO for } 2-3 \\
\text { days }\end{array}$ & $\mathrm{n}=18(78 \%)$ \\
\hline 2 & Syzygium cumini $(\mathrm{n}=11)$ & $\begin{array}{l}\text { Dried seed } 125 \mathrm{~g}+ \\
\text { Jaggery } 125 \mathrm{~g}\end{array}$ & $\begin{array}{l}\text { Pulverized, given } \\
\text { PO for 2-3 days }\end{array}$ & $\mathrm{n}=8(73 \%)$ \\
\hline 3 & $\begin{array}{l}\text { Nicotiana tabacum } \\
(\mathrm{n}=22)\end{array}$ & dried leaf $30-50 \mathrm{~g}$ & $\begin{array}{l}\text { Pulverized, given } \\
\text { PO for 2-3 days }\end{array}$ & $\mathrm{n}=17(77 \%)$ \\
\hline 4 & kortumba seeds $(n=15)$ & $\begin{array}{l}\text { dried seed } 30- \\
50 \mathrm{~g}\end{array}$ & $\begin{array}{l}\text { Pulverized, given } \\
\text { PO for 2-3 days }\end{array}$ & $\mathrm{n}=11(73 \%)$ \\
\hline 5 & $\begin{array}{l}\text { Sesamum indicum } \\
(\mathrm{n}=13)\end{array}$ & $\begin{array}{l}50-60 \mathrm{gm} \text { dried } \\
\text { leaves }\end{array}$ & $\begin{array}{l}\text { Pulverized, given } \\
\text { PO for 2-3 days }\end{array}$ & $\mathrm{n}=10(77 \%)$ \\
\hline 6 & $\begin{array}{l}\text { Dried tea leaves }(n=16) \\
\text { (miscellaneous EVP) }\end{array}$ & dried leaf $30-50 \mathrm{~g}$ & $\begin{array}{l}\text { Pulverized, given } \\
\text { PO for 2-3 days }\end{array}$ & $\mathrm{n}=11(69 \%)$ \\
\hline
\end{tabular}

Farmers still rely on ethno veterinary medicines for reproductive management of their animals. However these practices should be documented by the institutes for their scientific basis and can then be popularized for production of organic livestock produce. Exclusive awareness campaigns will be needed in a comprehensive way for promoting valid ethno-veterinary practices in the livestock farmers.

\section{References}

Abbas, B., A. A. Al-Qarawi and A.Al-Hawas, 2002. The ethno-veterinary knowledge and practice of traditional healers in Qassim Region, Saudi Arabia. J. Arid Environ., 50:367-379.

Bianco, V.V. and Boari, F. (1997) In: Rocket: A Meditrranean Crop lor. the Wonft IPGRI, Rome Italy, pp-41-49.

Bullitta, S., G. Piluzza and L.Viegi, 2007. Plant resources used for traditional ethnoveterinary phytotherapy in Sardinia (Italy). Genet. Resour. Crop Evol., 54: 1447-1464.

Davis, D.K., K. Quraishi, D. Sherman, A. Sollad and C. Stem, 1995. Ethno veterinary medicine in Afghanistan: an overview of indigenous animal health care among Pashtun Koochi nomads. J. Arid Environ., 31:483-500.

Fielding D. 1998. Ethnoveterinary medicine in the tropics-Key issues and the way forward? Paper presented to the tropical agricultural association seminar on Sep.26th 1998, on local knowledge in tropical agricultural research and development. Durham University, Durham, UK.

Guarrera, P.M., 1999. Traditional anthelmintic, antiparasitic and repellent uses of plants in Central Italy. J. Ethnopharmacol., 68: 183-192.

Islam, M.M. and M.A. Kashem, 1999. Farmer's use of ethno-veterinary medicine $(\mathrm{EVM})$ in the rearing and management of livestock: An empirical study in Bangladesh. J. Sustain. Agri.,13(4):39-57.

Kudi C A. 2003. Ethnoveterinary, complementary and low cost treatment and management of working animals. Paper presented at Workshop on The Challenge of Improving the Transport Animal Welfare in the World: Ways 
Forward, held at Silsoe Research Institute, Oxford. World Association for Transport Animal Welfare and Studies (TAWS). April 24, 2003. UK.

Lans, C., T. Harper, K. Georges and E. Bridgewater, 2000. Medicinal plants used for dogs in Trinidad and Tobago. Prev. Vet. Med., 45:201-220.

Mathias E. 2004. Ethno veterinary medicine: Harnessing its potential. Vet. Bull. 74(8): 27N-37N.

Mathias-Mundy E and McCorkle C M. 1989. Ethnoveterinary medicine: an Annotated Bibliography. Bibliographies in Technology and Social Change, No.6, Pp.199. Technology and Social Change Programme, Iowa State University, Ames, Iowa 50011. USA.

Monteiro A M, Wanyangu S, Kariuki D P, Bain R, Jackson F et al., 1998. Pharmaceutical quality of anthelmintics sold in Kenya. Vet Rec 142: 396-98.

Muhammad, G., M.Z. Khan, M.H. Hussain, Z. Iqbal, M. Iqbal and M. Athar, 2005. Ethno veterinary practices of owners of pneumatic-cart pulling camels in Faisalabad city (Pakistan). J. Ethnopharmacol. 97: 241-246.

Nfi A N, Mbanya J N, Ndi C, Kameni A, Vabi M, Pingpoh D, Yonkeu S and Moussa C. 2001. Ethno veterinary medicine in the northern provinces of Cameroon. Vet Res Commun 25: 71-76.

Perveen, F. and N. Bibi, 2008. Identification of Ixodid tick fauna and their local traditional control methods in Lakki Marwat and D.I.Khan, NWFP. 35th All
Pakistan Science Conference held in Dec. 2008.

Pieroni, A., P. Howard, G. Volpato and R.F.Santoro, 2004. Natural remedies and nutraceuticals used in ethnoveterinary practices in Inland southern Italy. Vet. Res. Commun., 28:55-80.

Sharma R K. 2004. Studies on minerals and hormonal interventions on reproductive performance of buffaloes in different agro-climatic Zones of Punjab. PhD. Thesis, Punjab Agricultural University, Ludhiana.

Tabuti J R S, Dhillion S S and Lye K A. 2003. Ethno veterinary medicine for cattle (Bos indicus) in Bulamogi county Uganda: plant species and mode of use. J Ethnopharm 88:279-286.

Uncini Manganelli, R.E., F. Camangi and P.E. Tomei, 2001. Curing animals with plants: Traditional usage in Tuscany (Italy). J. Ethnopharmacol., 78:171-191.

Viegi, L., A. Pieroni, P.M. Guarrera and R. Vangelisti, 2003. A review of plants used in folk veterinary medicine in Italy as basis for a databank. J. Ethnopharmacol., 89:221-244.

Wirtu, G., G. Adugna, T. Samuel, E. Kelbessa and A.Geleto, 1997. Aspects of farmers' knowledge, attitudes and practices of animal health problems in central Ethiopia. In: Proc. Intl.Conference Ethnoveterinary Medicine: Alternatives for Livestock Development. Organized by BAIF Development Res.Foundation.4-6 Nov.1997, Pune, India, and Vol.1.

\section{How to cite this article:}

Dey, S., B. K. Sarkar and Paul. S. R. 2020. Ethno-Veterinary Practices for the Management of Common Diseases in Dairy Animals in Rural Punjab. Int.J.Curr.Microbiol.App.Sci. 9(07): 447452. doi: https://doi.org/10.20546/ijcmas.2020.907.050 